\author{
ANNA CZAPLIŃSKA \\ Uniwersytet Szczeciński, Polska \\ University of Szczecin, Poland
}

\title{
Charakterystyka rynku ksiązki na podstawie scenariuszy stanów otoczenia
}

\section{Characteristics of the Book Market Based on Scenarios of Environment Conditions}

\begin{abstract}
Streszczenie: Książki są produktem finalnym procesu, na który składają się: etap indywidualnego lub zbiorowego procesu twórczego, etap produkcyjny realizowany w przedsiębiorstwach przemysłu poligraficznego oraz etap usługowy polegający na upowszechnianiu, dystrybucji i komercjalizacji produktu. Całość procesu jest więc bardzo złożona ze względu na jego naprzemienny niematerialny i materialny charakter, który poza wymiarem ekonomicznym ma w sobie również wymiar społeczny. Stąd też duża wrażliwość tego produktu na zachodzące procesy w sferze szeroko pojętej kultury podatnej na wpływy otoczenia krajowego, ale determinowane przez procesy globalne. Celem pracy jest ogólna charakterystyka rynku książki w perspektywie strategicznej w świetle dynamicznych przemian zachodzących w jego otoczeniu. Zastosowanie metody scenariuszy stanów otoczenia do analizy rynku książki miało na celu lepszą identyfikację tych składników makrootoczenia, które mogą mieć decydujący wpływ na funkcjonowanie rynku książki. Na podstawie otrzymanych wyników wydaje się, że najprawdopodobniej nastąpi dalszy wzrost dostępu do tekstu książki w oparciu o nowoczesne technologie. Kluczowym czynnikiem decydującym o dalszym rozwoju wszystkich ogniw rynku książki będzie jednak czynnik społeczno-kulturowy, który związany jest z przejściem w kierunku społeczeństwa informacyjnego (hipertekstowego) w którym istotna jest sama informacja oraz wygodny nośnik jej przekazu.
\end{abstract}

\begin{abstract}
Books are the final product of the process, which consists of the phase of an individual or collective creative process, production phase implemented in the enterprises of the printing industry and the service phase consisting in the dissemination, distribution and commercialisation of the product. The whole process is therefore very complex due to its alternating intangible and material nature, which, apart from the economic dimension, also has a social dimension. Therefore, the product is highly sensitive to the processes occurring in the broad culture susceptible to national environmental influences determined by global processes. The goal of the work was a general description of the book market presented in a strategic perspective in the light of dynamic changes taking place in its environment. The use of the scenario method of environment conditions for analysing the book market was used to better identify the macro-environment components that can have a decisive impact on the functioning of the book market. Based on the results obtained, it seems that there will probably be a further increase in access to the texts, based on modern technologies. The key factor determining the further development of all links in the book market will be the socio-cultural factor, which is associated with the transition towards information society (hypertext) in which information itself and the convenient medium of its message are important.
\end{abstract}


Słowa kluczowe: hipertekst; rynek książki; scenariusze stanów otoczenia; składniki makrootoczenia

Keywords: book market; hypertext; macro-environment components; scenario method of environment conditions

Otrzymano: 9 stycznia 2020

Received: 9 January 2020

Zaakceptowano: 20 marca 2020

Accepted: 20 March 2020

Sugerowana cytacja / Suggested citation:

Czaplińska, A. (2020). Charakterystyka rynku książki na podstawie scenariuszy stanów otoczenia. Prace Komisji Geografii Przemysłu Polskiego Towarzystwa Geograficznego, 34(2), 144-155. doi 10.24917/ 20801653.342.10

\section{WSTĘP}

Niezależnie od potocznych i fachowych określeń klasycznej książki oraz sporu o to, jaka jest jej rola we współczesnej kulturze, edukacji czy sztuce informacji, kluczowe wydaje się stwierdzenie, że jest ona towarem i jak każde dobro materialne w konkurencyjnej gospodarce podlega mechanizmom rynkowym i wszelkim jego prawom. Oczywiście, jak każdy towar, książka ma swoją specyfikę, choćby dlatego, że jest produktem kultury, dokumentem twórczej myśli ludzkiej, który oddziałuje długofalowo, kształtując poglądy i postawy obywateli, generując rozwój kulturalny, naukowy, techniczny i gospodarczy społeczeństw (Gołębiewski, 2010; Drapińska, Liberadzka, 2017).

Książka jest też produktem finalnym procesu, na który składają się: etap indywidualnego lub zbiorowego procesu twórczego, etap produkcyjny realizowany w przedsiębiorstwach przemysłu poligraficznego oraz etap usługowy polegający na upowszechnieniu, dystrybucji i komercjalizacji produktu. Całość procesu jest więc bardzo złożona ze względu na jego naprzemienny niematerialny i materialny charakter, który poza wymiarem ekonomicznym ma w sobie również wymiar społeczny.

Nie zmienia to faktu, że rynek książki, przy całej swej złożoności, funkcjonuje i jak każdy inny poddawany jest wieloaspektowym analizom socjologicznym, bibliologicznym, kulturoznawczym, ekonomicznym, geograficznym, politycznym itp. (np. Rychlewski, 2013; Zygierewicz, 2015; Augustyn, 2017; Turrin, 2017; Koryś, Michalak, Zasacka, Chymkowski, 2018). Jest szczególnie wrażliwy na zagrożenia zewnętrzne, takie jak np. podnoszona na nowo teza kanadyjskiego filozofa M. McLuhana o końcu „epoki słowa drukowanego" (1962). Odbywająca się ewolucja mediów powoduje wprowadzanie na rynek nowych nośników i nowych formatów, ale istota rzeczy, czyli samo czytanie, pozostaje niezmienne. Za słuszną należy uznać tezę R. Osiewały (2013: 300), zgodnie z którą: „Kto nie czyta książek papierowych, raczej nie zainteresuje się e-bookami”. Znacznie bardziej niebezpieczne dla rynku książek wydaje się promowanie hipertekstu (czego przykładem jest internet), a nie tekstu linearnego. Szczególnie dla pokolenia $\mathrm{Z}$ formowanego od najmłodszych lat $\mathrm{w}$ duchu hipertekstu tekst linearny pozbawiony usieciowienia i multimedialnej oprawy jest nieatrakcyjny, niezrozumiały i trudny do przyswojenia (Dobrowolski, 2001). Ale nie dotyczy to tylko młodego pokolenia. Stając się społeczeństwem informacyjnym, stajemy się też pokoleniem hipertekstowym. To wydaje się praprzyczyną pogarszającej się sytuacji w czytelnictwie, która w sposób oczywisty rzutuje na rynek książki. 
Uznając rynek książki za istotny element kulturowy, który jednak podlega weryfikacji rynkowej, celem pracy była ogólna charakterystyka polskiego rynku książki w perspektywie strategicznej, tj. trzech-pięciu lat, w świetle dynamicznych przemian zachodzących w jego otoczeniu. Uzyskane w ten sposób wyniki mogą posłużyć do przygotowania strategii reagowania na zdiagnozowane problemy rynku książki, co zostało uznane przez autora za dalszy krok badawczy wymagający jednak pogłębionych badań. Stąd nie uwzględniono tego elementu w przeprowadzonej analizie.

\section{SYTUACJA NA RYNKU KSIĄŻKI - ANALIZA STANÓW OTOCZENIA}

Mimo okresowych małych stabilizacji w dłuższej perspektywie czasowej rynek książki w Polsce notuje powolny spadek wartości. Przyczyny tego faktu są powszechnie znane i dotyczą m.in. niekorzystnych rozstrzygnięć w segmencie podręczników szkolnych, braku regulacji rynku dystrybucji książek w kontekście jednolitej ceny i kanałów dystrybucji, rozbieżne cele w obszarze wydawniczym i dystrybucyjnym, a nade wszystko słabnący popyt. Chcąc utrzymać się na rynku, wielu wydawców kieruje się w stronę rozwiązań doraźnych, które pozwalają na funkcjonowanie w granicach rentowności operacyjnej, ale w dłuższym horyzoncie czasowym działania te nie przynoszą zamierzonych efektów. Warto jednak zwrócić większą uwagę na zewnętrzne otoczenie rynku, tego, co staje się szansą, a co zagrożeniem będącym konsekwencją rozwoju cywilizacyjnego, w tym postępu technologicznego, procesów ekonomicznych oraz przemian społeczno-kulturowych, które w sposób oczywisty rzutują na postawy wobec sfery prawno-regulacyjnej.

W świetle powyższych ustaleń za celowe uznano wykorzystanie prognozowania długookresowego do antycypowania przyszłości i oceny potencjalnego ryzyka na rynku książek. W badaniach wykorzystano metodę scenariuszy stanów otoczenia, która ma w założeniu charakter jakościowy. Oznacza to ocenę potencjalnej siły wpływu poszczególnych procesów występujących w otoczeniu rynku książki oraz szacowania prawdopodobieństwa wystąpienia tych procesów w określonej przyszłości (Gierszewska, Romanowska, 2002). Warto dodać, że metody scenariuszowe, do których należy zaproponowana metoda badawcza, niosą ze sobą duży ładunek subiektywizmu, którego źródłem jest sama istota prognozowania, niezależnie od stopnia wiedzy i doświadczenia autorów. Stąd niejednoznaczny odbiór stosowania tego rodzaju metod. Należy podkreślić, że metoda stanów otoczenia jest obecnie stosowana we wstępnej analizie oceny możliwości rozwojowych przedsiębiorstw czy całych rynków i nie podlega istotnej krytyce przy jasno określonych słabościach (m.in. Kozioł, 2010; Kwiecińska, 2016). Podejście autora ma jedynie wskazać inny, alternatywny opis otoczenia rynku książki.

Na podstawie ogólnodostępnych informacji pochodzących z wielu źródeł, takich jak portale Rynek Książki, Instytut Książki, strona internetowa Biblioteki Narodowej (bn.org.pl) oraz publikacji zwartych takich jak Rynek książki w Polsce zidentyfikowano te składniki makrootoczenia, które mogą mieć decydujący wpływ na funkcjonowanie rynku książki. Wstępnie dokonano redukcji zidentyfikowanych czynników, a czasem ich uogólnienia oraz pogrupowano w sfery. Zrezygnowano z opisu wybranych czynników, uznając, że ich treść jest wystarczająco czytelna, a istotność potwierdzona w przytoczonych źródłach. W makrootoczeniu wyróżniono cztery kluczowe sfery: ekonomiczną, regulacyjną, technologiczną oraz społeczno-kulturową. Podział otoczenia na sfery 
zmniejsza niebezpieczeństwo jego jednostronnego traktowania, a ponadto zwiększa precyzję identyfikowania zachodzących w nim procesów (tabela 1).

Tabela 1. Składniki otoczenia rynku książki według przyjętych sfer

\begin{tabular}{|c|c|c|c|c|}
\hline Sfera & Czynnik & Trend & $\begin{array}{c}\text { Siła } \\
\text { wpływu }\end{array}$ & Prawdopodobieństwo \\
\hline \multirow{15}{*}{ Ekonomiczna } & \multirow{3}{*}{ Skutki open source dla autorów } & wzrost & -3 & 0,6 \\
\hline & & stabilizacja & +1 & 0,2 \\
\hline & & regres & -3 & 0,2 \\
\hline & \multirow{3}{*}{$\begin{array}{l}\text { Rozwój systemów subskrypcji } \\
\text { zapewnia tani dostęp }\end{array}$} & wzrost & +3 & 0,6 \\
\hline & & stabilizacja & +1 & 0,3 \\
\hline & & regres & -2 & 0,1 \\
\hline & \multirow{3}{*}{ Nadpodaż tytułów } & wzrost & -3 & 0,6 \\
\hline & & stabilizacja & -2 & 0,2 \\
\hline & & regres & +3 & 0,2 \\
\hline & \multirow{3}{*}{ Wojny cenowe } & wzrost & -3 & 0,4 \\
\hline & & stabilizacja & -2 & 0,3 \\
\hline & & regres & +2 & 0,3 \\
\hline & \multirow{3}{*}{$\begin{array}{l}\text { Względnie słaba siła nabywcza } \\
\text { grup docelowych }\end{array}$} & wzrost & -3 & 0,4 \\
\hline & & stabilizacja & -1 & 0,5 \\
\hline & & regres & +3 & 0,1 \\
\hline \multirow{15}{*}{ Technologiczna } & \multirow{3}{*}{$\begin{array}{l}\text { Rozwój urządzeń mobilnych } \\
\text { do czytania }\end{array}$} & wzrost & +2 & 0,8 \\
\hline & & stabilizacja & +1 & 0,1 \\
\hline & & regres & -2 & 0,1 \\
\hline & \multirow{3}{*}{ Globalizacja kanałów dystrybucji } & wzrost & -3 & 0,7 \\
\hline & & stabilizacja & -1 & 0,2 \\
\hline & & regres & +2 & 0,1 \\
\hline & \multirow{3}{*}{$\begin{array}{l}\text { Optymalizacja produkcji książek, } \\
\text { w tym druk na żądanie }\end{array}$} & wzrost & +2 & 0,6 \\
\hline & & stabilizacja & +1 & 0,3 \\
\hline & & regres & -2 & 0,1 \\
\hline & \multirow{3}{*}{$\begin{array}{l}\text { Rozwój dystrybucji dedykowanej, } \\
\text { np. dla bibliotek }\end{array}$} & wzrost & +3 & 0,6 \\
\hline & & stabilizacja & -1 & 0,3 \\
\hline & & regres & -3 & 0,1 \\
\hline & \multirow{3}{*}{$\begin{array}{l}\text { Rozwój platform } \\
\text { selfpublishingowych }\end{array}$} & wzrost & +2 & 0,7 \\
\hline & & stabilizacja & +1 & 0,2 \\
\hline & & regres & -2 & 0,1 \\
\hline \multirow{9}{*}{ Regulacyjna } & \multirow{3}{*}{ Społeczna akceptacja reprografii } & wzrost & -3 & 0,3 \\
\hline & & stabilizacja & -2 & 0,4 \\
\hline & & regres & +3 & 0,3 \\
\hline & \multirow{3}{*}{$\begin{array}{l}\text { Systemy subskrypcji zapewniające } \\
\text { legalny dostęp }\end{array}$} & wzrost & +2 & 0,6 \\
\hline & & stabilizacja & +1 & 0,3 \\
\hline & & regres & -2 & 0,1 \\
\hline & \multirow{3}{*}{$\begin{array}{l}\text { Nielegalna dystrybucja treści } \\
\text { książek w sieci }\end{array}$} & wzrost & -3 & 0,3 \\
\hline & & stabilizacja & -2 & 0,4 \\
\hline & & regres & +3 & 0,3 \\
\hline
\end{tabular}




\begin{tabular}{|c|c|c|c|c|}
\hline \multirow{6}{*}{$\begin{array}{l}\text { Regulacyjna } \\
\text { (cd.) }\end{array}$} & \multirow{3}{*}{ Jednolita cena książki } & wzrost & +1 & 0,3 \\
\hline & & stabilizacja & -1 & 0,5 \\
\hline & & regres & -2 & 0,2 \\
\hline & \multirow{3}{*}{$\begin{array}{l}\text { Książka w mediach } \\
\text { społecznościowych (BookRage) }\end{array}$} & wzrost & +1 & 0,7 \\
\hline & & stabilizacja & -1 & 0,2 \\
\hline & & regres & -2 & 0,1 \\
\hline \multirow{15}{*}{$\begin{array}{l}\text { Społeczno- } \\
\text {-kulturowa }\end{array}$} & \multirow{3}{*}{$\begin{array}{l}\text { Kreowanie popytu na książki } \\
\text { przez internet }\end{array}$} & wzrost & -2 & 0,8 \\
\hline & & stabilizacja & +1 & 0,1 \\
\hline & & regres & +2 & 0,1 \\
\hline & \multirow{3}{*}{$\begin{array}{l}\text { Preferowanie hipertekstu, } \\
\text { a nie tekstu linearnego }\end{array}$} & wzrost & -3 & 0,7 \\
\hline & & stabilizacja & -2 & 0,2 \\
\hline & & regres & +3 & 0,1 \\
\hline & \multirow{3}{*}{$\begin{array}{l}\text { Utrata prestiżu zawodów } \\
\text { związanych z książką }\end{array}$} & wzrost & -1 & 0,6 \\
\hline & & stabilizacja & -1 & 0,3 \\
\hline & & regres & +1 & 0,1 \\
\hline & \multirow{3}{*}{$\begin{array}{l}\text { Rosnący konsumpcjonizm } \\
\text { społeczny }\end{array}$} & wzrost & -3 & 0,8 \\
\hline & & stabilizacja & -2 & 0,1 \\
\hline & & regres & +3 & 0,1 \\
\hline & \multirow{3}{*}{$\begin{array}{l}\text { Każdy chce wydać } \\
\text { książkę - nadpodaż }\end{array}$} & wzrost & -2 & 0,6 \\
\hline & & stabilizacja & -1 & 0,3 \\
\hline & & regres & +3 & 0,1 \\
\hline
\end{tabular}

Źródło: opracowanie własne

Przyjęto skalę ocen w układzie punktowym i znaczeniowym. W ocenie potencjalnej negatywnej lub pozytywnej siły wpływu czynnika przyjęto skale oceniania od -3 do +3 , według wzorca: -3 - duża negatywna siła oddziaływania; -2 - średnia negatywna siła oddziaływania; -1 - mała negatywna siła oddziaływania; +1 - mała pozytywna siła oddziaływania; +2 - średnia pozytywna siła oddziaływania; +3 - duża pozytywna siła oddziaływania. Drugim wymiarem oceny było określenie prawdopodobieństwa wystąpienia danego zjawiska, w skali 0-1. Suma prawdopodobieństwa dla każdego czynnika wynosi 1.

Przedstawione kryteria oceny w odniesieniu do każdego procesu w otoczeniu mogą być subiektywne, a z całą pewnością są zmienne i zależne od istoty tego procesu. Niemniej zaproponowana metodologia wymaga pewnego uogólnienia i standaryzacji. Warto także dodać, że zaliczenie konkretnych zjawisk do określonej sfery nastręcza mnóstwo trudności. W wielu przypadkach występują bowiem elementy pozwalające na zaliczenie ich jednocześnie do dwóch lub więcej sfer. Na podstawie dokonanej oceny zbudowano scenariusze stanów otoczenia rynku książki (tabele 2, 3, 4).

W scenariuszu optymistycznym na uwagę zasługują zwłaszcza sfera ekonomiczna i społeczno-kulturowa, od których będzie zależeć powodzenie tego scenariusza. Równocześnie większość czynników w obu sferach ma charakter regresu. Można zatem przyjąć, że scenariusz optymistyczny bazuje na wyhamowaniu, ograniczeniu zachodzących procesów, które w większości przypadków możemy uznać za negatywne (tabela 2). 
Tabela 2. Scenariusz optymistyczny

\begin{tabular}{|c|c|c|c|}
\hline Sfera & Czynnik & Trend & $\begin{array}{c}\text { Siła } \\
\text { wpływu }\end{array}$ \\
\hline \multirow{6}{*}{ Ekonomiczna } & Skutki open source dla autorów & stabilizacja & +1 \\
\hline & Rozwój systemów subskrypcji zapewnia tani dostęp & wzrost & +3 \\
\hline & Nadpodaż tytułów & regres & +3 \\
\hline & Wojny cenowe & regres & +2 \\
\hline & Względnie słaba siła nabywcza grup docelowych & regres & +3 \\
\hline & Średnia siła wpływu & $\mathbf{x}$ & 2,4 \\
\hline \multirow{6}{*}{ Technologiczna } & Rozwój urządzeń mobilnych do czytania & wzrost & +2 \\
\hline & Globalizacja kanałów dystrybucji & regres & +2 \\
\hline & Optymalizacja produkcji książek, w tym druk na żądanie & wzrost & +2 \\
\hline & Rozwój dystrybucji dedykowanej, np. dla bibliotek & wzrost & +3 \\
\hline & Rozwój platform selfpublishingowych & wzrost & +2 \\
\hline & Średnia siła wpływu & $\mathbf{x}$ & 2,2 \\
\hline \multirow{6}{*}{ Regulacyjna } & Społeczna akceptacja reprografii & regres & +3 \\
\hline & Systemy subskrypcji zapewniające legalny dostęp & wzrost & +2 \\
\hline & Nielegalna dystrybucja treści książek w sieci & regres & +3 \\
\hline & Jednolita cena książki & wzrost & +1 \\
\hline & Książka w mediach społecznościowych (BookRage) & wzrost & +1 \\
\hline & Średnia siła wpływu & $\mathbf{x}$ & 2,0 \\
\hline \multirow{6}{*}{$\begin{array}{l}\text { Społeczno- } \\
\text {-kulturowa }\end{array}$} & Kreowanie popytu na książki przez internet & regres & +2 \\
\hline & Preferowanie hipertekstu, a nie tekstu linearnego & regres & +3 \\
\hline & Utrata prestiżu zawodów związanych z książką & regres & +1 \\
\hline & Rosnący konsumpcjonizm społeczny & regres & +3 \\
\hline & Każdy chce wydać książkę - nadpodaż & regres & +3 \\
\hline & Średnia siła wpływu & $\mathbf{x}$ & 2,4 \\
\hline
\end{tabular}

Źródło: opracowanie własne

W sferze ekonomicznej optymizm tego scenariusza miałby dotyczyć regresu w nadpodaży tytułów, których liczba nie przekłada się na jakość tak pod względem technicznym, jak i merytorycznym. Nadmiar tytułów wprowadza niepotrzebny niepokój intelektualny podczas procesu wyboru tytułu, który często ma kilka, a w skrajnych przypadkach kilkanaście tytułów zastępczych. Problem ten jest o tyle ważny, że dotyka również edukacji (podręczniki szkolne) oraz nauki (czasopisma naukowe). Scenariusz optymistyczny zakłada również przynajmniej ograniczenie prowadzonej twardej polityki cenowej na rynku książki, to znaczy takiej, w której niska cena wydaje się najistotniejszą przewagą rynkową. Taka strategia może być skuteczna przy sygnalizowanej wielkości podobnych tytułów, ale prowadzi do deprecjacji nakładów intelektualnych autorów oraz wszystkich tych, którzy przyczynili się do powstania książki. Inaczej mówiąc, zbyt niska cena książki nie budzi zaufania do jej treści oraz jej autorów. Dążenie do niskiej ceny jest również odpowiedzią na względnie słabą siłę nabywczą grup docelowych, ale nie możemy zakładać, że siła ta będzie zawsze słaba. 
Zależy to m.in. od tego, jaką ostatecznie pozycję zajmie książka na rynku, jak zostanie wyceniona pod względem swojej użyteczności oraz prestiżu posiadania. Tylko dwa czynniki w sferze ekonomicznej nie mają charakteru regresywnego. Dotyczy to rozwoju systemu subskrypcji, który jest bezwzględnie potrzebny w dobie dość dowolnie interpretowanej własności intelektualnej tekstów, a jednocześnie rosnącej popularności open source. Wydaje się, że potrzebna jest tu pewna równowaga, wynikająca np. ze stopnia zaawansowania wiedzy zawartej w tekście. Przyjęcie jakiegokolwiek skrajnego rozwiązania będzie powodować sprzeciw i naturalne poszukiwanie alternatywy na granicy prawa autorskiego.

Scenariusz optymistyczny w sferze społeczno-kulturowej oznacza regres wszystkich uwzględnionych czynników. Ale kluczowe wydają się tutaj trzy elementy, a wśród nich wspomniana już nadpodaż tytułów, silnie stymulowana nie tylko przez samych autorów, ale również przez wydawnictwa oraz media internetowe, które w poszukiwaniu zysku przekonują, że każdy może napisać książkę. Czynnik ten jest z kolei w kontrze do innego, tj. do rosnącego konsumpcjonizmu społecznego, wyrosłego $\mathrm{z}$ materializmu, w którym akcent jest położony na mieć, a nie być. Można więc zaryzykować tezę, że każdy chce napisać książkę, którą może postawić na półce, ale z licznym gronem czytelników mogą być trudności.

Jednak najważniejszy z czynników w tej sferze wydaje się ten, który dotyczy hipertekstu. Wydaje się, że jego rosnąca popularność może niepokoić w kontekście roli i znaczenia tekstu linearnego, którym zapisywany jest m.in. tekst książki. Atrakcyjność hipertekstu, którego istota polega na możliwości rozpoczęcia czytania od dowolnego fragmentu (węzła), a usieciowienie oraz multimedialność sprawiają, że efekt znużenia następuje znacznie później niż w przypadku tekstu klasycznej książki. Ale trzeba zwrócić uwagę na to, że stworzona struktura hipertekstu może być niepełna (co ogranicza lub uniemożliwia jego funkcjonalność) lub mieć w założeniu manipulację. Niezależnie od przytoczonych argumentów dalsze upowszechnianie się hipertekstu jest jedną z najważniejszych, jeśli nie najważniejszą przyczyną spadku zainteresowania książką nie tylko w sferze społeczno-kulturowej. Ma ona jednak charakter trendu globalnego, więc próba jego ograniczania wydaje się bardzo trudna.

Spośród pozostałych istotnych czynników w uwzględnionych sferach budujących scenariusz optymistyczny warto zwrócić uwagę na dwa czynniki ze sfery regulacyjnej. Są to: społeczna akceptacja reprografii oraz nielegalna dystrybucja treści książek w sieci. Oba o jednoznacznie regresywnym charakterze i maksymalnej sile wpływu. Ograniczenie obu zjawisk tak jak poprzednio sygnalizowanych jest zadaniem bardzo trudnym, ale wydaje się, że ich skutki mógłby ograniczyć rozwój legalnej dystrybucji, w tym dystrybucji do instytucji edukacyjnych, bibliotek itp. Proces taki następuje, ale jego skala i utarte schematy wymagają znacznie dłuższego czasu.

W scenariuszu pesymistycznym na szczególną uwagę zasługuje sfera ekonomiczna, która wydaje się najbardziej narażona na procesy zachodzące $\mathrm{w}$ otoczeniu rynku książki. Siła wpływu tej sfery przewyższa nie tylko pozostałe sfery scenariusza pesymistycznego, ale również wszystkie sfery w scenariuszu optymistycznym. Jeżeli większość zidentyfikowanych w tej sferze czynników utrzyma swój wzrost (wyjątek stanowi tu rozwój systemów subskrypcji), to będzie to miało duże negatywne konsekwencje finansowe dla wszystkich uczestników rynku. Negatywne oceny pozostałych sfer w scenariuszu pesymistycznym są łagodniejsze (tabela 3). 
Tabela 3. Scenariusz pesymistyczny

\begin{tabular}{|c|c|c|c|}
\hline Sfera & Czynnik & Trend & $\begin{array}{c}\text { Siła } \\
\text { wpływu }\end{array}$ \\
\hline \multirow{6}{*}{ Ekonomiczna } & Skutki open source dla autorów & wzrost & -3 \\
\hline & Rozwój systemów subskrypcji zapewnia tani dostęp & regres & -2 \\
\hline & Nadpodaż tytułów & wzrost & -3 \\
\hline & Wojny cenowe & wzrost & -3 \\
\hline & Względnie słaba siła nabywcza grup docelowych & wzrost & -3 \\
\hline & Średnia siła wpływu & $\mathbf{x}$ & $-2,8$ \\
\hline \multirow{6}{*}{ Technologiczna } & Rozwój urządzeń mobilnych do czytania & regres & -2 \\
\hline & Globalizacja kanałów dystrybucji & wzrost & -3 \\
\hline & Optymalizacja produkcji książek, w tym druk na żądanie & regres & -2 \\
\hline & Rozwój dystrybucji dedykowanej, np. dla bibliotek & regres & -3 \\
\hline & Rozwój platform selfpublishingowych & regres & -2 \\
\hline & Średnia siła wpływu & $\mathbf{x}$ & $-2,4$ \\
\hline \multirow{6}{*}{ Regulacyjna } & Społeczna akceptacja reprografii & wzrost & -3 \\
\hline & Systemy subskrypcji zapewniające legalny dostęp & regres & -2 \\
\hline & Nielegalna dystrybucja treści książek w sieci & wzrost & -3 \\
\hline & Jednolita cena książki & regres & -2 \\
\hline & Książka w mediach społecznościowych (BookRage) & regres & -2 \\
\hline & Średnia siła wpływu & $\mathbf{x}$ & $-2,4$ \\
\hline \multirow{6}{*}{$\begin{array}{l}\text { Społeczno- } \\
\text {-kulturowa }\end{array}$} & Kreowanie popytu na książki przez internet & wzrost & -2 \\
\hline & Preferowanie hipertekstu, a nie tekstu linearnego & wzrost & -3 \\
\hline & Utrata prestiżu zawodów związanych z książką & wzrost & -1 \\
\hline & Rosnący konsumpcjonizm społeczny & wzrost & -3 \\
\hline & Każdy chce wydać książkę - nadpodaż & wzrost & -2 \\
\hline & Średnia siła wpływu & $\mathbf{x}$ & $-2,2$ \\
\hline
\end{tabular}

Źródło: opracowanie własne

Uzasadnienie roli i znaczenia poszczególnych czynników w scenariuszu pesymistycznym jest podobne jak w przypadku scenariusza optymistycznego, tylko z przeciwnym znakiem. Stąd w celu uniknięcia powtórzeń pominięto ten element. Ale równie istotne co analiza wewnętrzna scenariuszów wydaje się analiza burzliwości otoczenia i stopnia uzależnienia rynku książki od zmian w nim zachodzących. Przyjmuje się bowiem, że im większa rozpiętość między scenariuszem optymistycznym a scenariuszem pesymistycznym w poszczególnych sferach, tym silniejsze jest uzależnienie rynku od otoczenia. Oznacza to, że takiej sferze należy poświęcić szczególnie dużo uwagi (Gierszewska, Romanowska, 2002; Penc-Pietrzak, 2010).

W omawianym przypadku badań otoczenia rynku książki największą rozpiętość uzyskała sfera ekonomiczna (5,2 pkt), a w dalszej kolejności sfery technologiczna i społeczno-kulturowa (4,6 pkt) oraz sfera regulacyjna (4,4 pkt). Wydaje się, że uzyskane wyniki potwierdzają uzależnienie rynku książki w główniej mierze od czynników natury ekonomicznej, niemniej, co warte podkreślenia, większość z uwzględnionych w badaniu 20 czynników jest ze sobą silnie powiązana, tworząc czasem związek o zależności kulistej, w którym trudno jest dociec, co jest faktyczną przyczyną, a co jej skutkiem (tabela 1). 
Rycina 1. Otoczenie rynku książki - źródła szans i zagrożeń

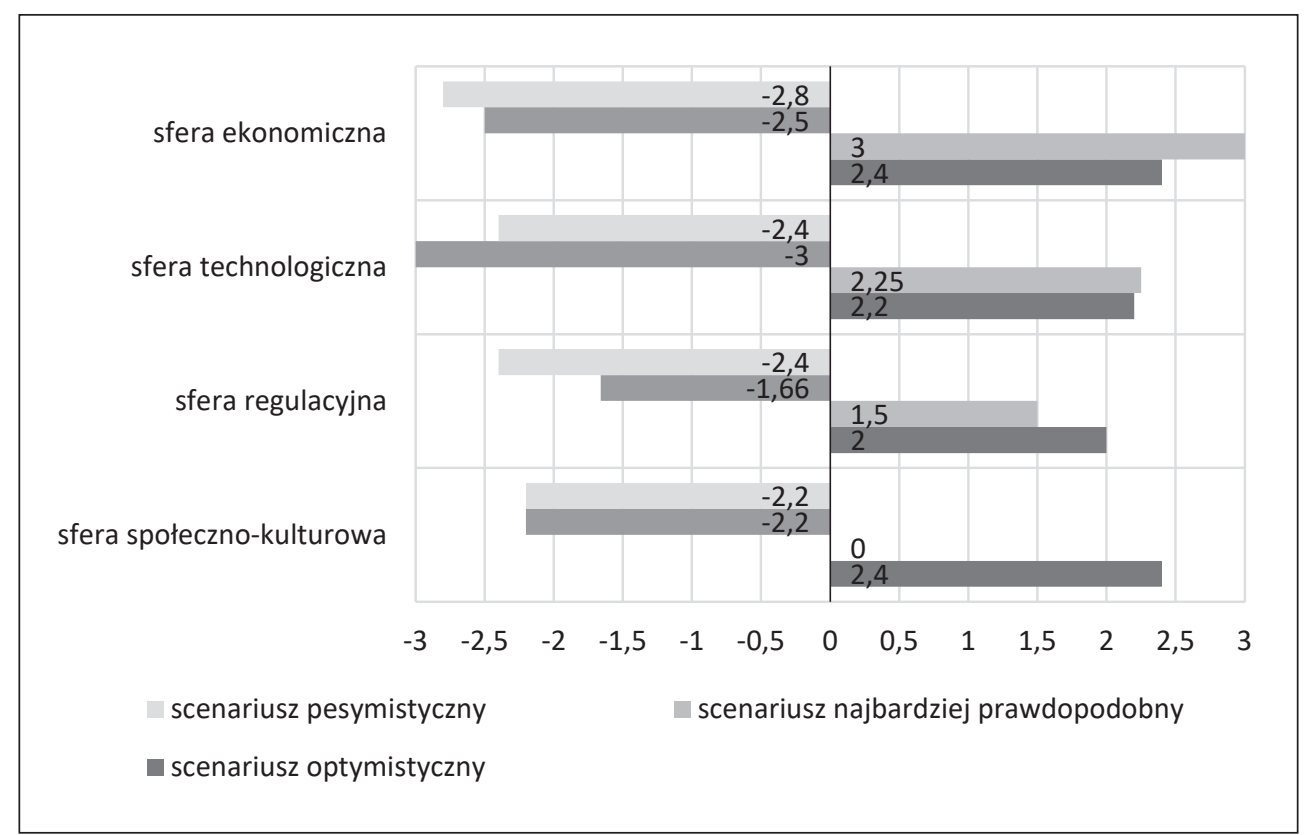

Źródło: opracowanie własne

Scenariusz najbardziej prawdopodobny składa się z trendów, które mają największe prawdopodobieństwo wystąpienia, niezależnie od potencjalnej siły pozytywnego czy negatywnego wpływu (tabela 4). W tym przypadku również można dokonać analizy burzliwości, uznając, że im rozpiętość scenariusza jest większa, tym bardziej niejednorodne i słabiej ustrukturalizowane będzie otoczenie. Otrzymane wyniki scenariusza najbardziej prawdopodobnego dla rynku książki wskazują, że najbardziej niejednorodna i najsłabiej ustrukturalizowana jest sfera ekonomiczna otoczenia rynku książki (5,5 pkt), a w dalszej kolejności znalazły się: sfera technologiczna (5,25 pkt), sfera regulacyjna $(3,16 \mathrm{pkt})$ oraz sfera społeczno-kulturowa (2,2 pkt) (tabela 4, rycina 1$)$. Otrzymane wyniki nie decydują jednak o istotności poszczególnych sfer i czynników, a jedynie podkreślają ich charakter i związek ze sobą. Pośrednio może to informować o nieprzewidywalności sfery lub (i) wpływać na możliwości interwencji w określoną sferę. To sfera ekonomiczna wydaje się najmniej przewidywalna.

Poddając bardziej wnikliwej ocenie otrzymany scenariusz najbardziej prawdopodobny, warto wyodrębnić tzw. procesy wiodące w otoczeniu, tj. takie, które mają silny wpływ na rynek książki (zarówno pozytywny, jak i negatywny) oraz duże prawdopodobieństwo wystąpienia. Do kluczowych pozytywnych procesów można zaliczyć procesy przede wszystkim ze sfery technologicznej, która generalnie ułatwia dostęp do tekstu książki, niezależnie od nośnika. Pojedyncze pozytywne procesy związane głównie ze subskrypcją oraz funkcjonowaniem książek w mediach społecznościowych występują w sferze ekonomicznej i regulacyjnej. Natomiast na szczególną uwagę zasługuje sfera społeczno-kulturowa, w której nie ma pozytywnego procesu, który wpływałby na rynek książki. Dodatkowo większość uwzględnionych procesów o ujemnej sile wpływu ma dużą i średnią siłę oddziaływania, co dodatkowo podkreśla ich ważność. Jest 
to o tyle ważne, a zarazem niebezpieczne, że procesy społeczno-kulturowe zachodzą zwykle w dłuższej perspektywie czasowej, a ich zmiana jest niekiedy niemożliwa do zrealizowania, bez względu na zaangażowane środki. Obok sfery społeczno-kulturowej najwięcej negatywnych czynników występuje w sferze ekonomicznej. Część z nich ma maksymalnie ujemną siłę wpływu. W tym przypadku jednak regulacje mogłyby nastąpić znacznie szybciej, pod warunkiem świadomości zachodzących procesów, ich powiązań oraz zwykłej dobrej woli, o co czasem trudno w grze rynkowej.

Tabela 4. Scenariusz najbardziej prawdopodobny

\begin{tabular}{|c|c|c|c|c|}
\hline \multirow{2}{*}{ Sfera } & \multirow[b]{2}{*}{ Czynnik } & \multirow[b]{2}{*}{ Trend } & \multicolumn{2}{|c|}{ Siła wpływu } \\
\hline & & & $\begin{array}{c}\text { Siła } \\
\text { wpływu } \\
\text { „ujemna” }\end{array}$ & \begin{tabular}{|c|} 
Siła \\
wpływu \\
„dodatnia”
\end{tabular} \\
\hline \multirow{6}{*}{ Ekonomiczna } & Skutki open source dla autorów & wzrost & -3 & \\
\hline & Rozwój systemów subskrypcji zapewnia tani dostęp & wzrost & & +3 \\
\hline & Nadpodaż tytułów & wzrost & -3 & \\
\hline & Wojny cenowe & wzrost & -3 & \\
\hline & Względnie słaba siła nabywcza grup docelowych & stabilizacja & -1 & \\
\hline & Średnia siła wpływu & & $-2,5$ & $+3,0$ \\
\hline \multirow{6}{*}{ Technologiczna } & Rozwój urządzeń mobilnych do czytania & wzrost & & +2 \\
\hline & Globalizacja kanałów dystrybucji & wzrost & -3 & \\
\hline & $\begin{array}{l}\text { Optymalizacja produkcji książek, w tym druk na } \\
\text { żądanie }\end{array}$ & wzrost & & +2 \\
\hline & Rozwój dystrybucji dedykowanej, np. dla bibliotek & wzrost & & +3 \\
\hline & Rozwój platform selfpublishingowych & wzrost & & +2 \\
\hline & Średnia siła wpływu & & $-3,0$ & $+2,25$ \\
\hline \multirow{6}{*}{ Regulacyjna } & Społeczna akceptacja reprografii & stabilizacja & -2 & \\
\hline & Systemy subskrypcji zapewniające legalny dostęp & wzrost & & +2 \\
\hline & Nielegalna dystrybucja treści książek w sieci & stabilizacja & -2 & \\
\hline & Jednolita cena książki & stabilizacja & -1 & \\
\hline & Książka w mediach społecznościowych (BookRage) & wzrost & & +1 \\
\hline & Średnia siła wpływu & & $-1,66$ & $+1,5$ \\
\hline \multirow{6}{*}{$\begin{array}{l}\text { Społeczno- } \\
\text {-kulturowa }\end{array}$} & Kreowanie popytu na książki przez internet & wzrost & -2 & \\
\hline & Preferowanie hipertekstu, a nie tekstu linearnego & wzrost & -3 & \\
\hline & Utrata prestiżu zawodów związanych z książką & wzrost & -1 & \\
\hline & Rosnący konsumpcjonizm społeczny & wzrost & -3 & \\
\hline & Każdy chce wydać książkę - nadpodaż & wzrost & -2 & \\
\hline & Średnia siła wpływu & & $-2,2$ & 0,0 \\
\hline
\end{tabular}

Źródło: opracowanie własne

Poza wymienionymi trzema scenariuszami można również oszacować potencjalną siłę zjawisk, które mogą niespodziewanie wpłynąć na rynek książki, tworząc tzw. scenariusz niespodziankowy. W większości przypadków dotyczyłoby to stagnacji omawianych procesów (czynników). Ich dotychczasowy przebieg, czasem gwałtowny, nie wskazuje jednak na to, aby w najbliższym czasie mogły nastąpić istotne zmiany, nawet w postaci wyhamowania zaobserwowanych trendów. 


\section{ZAKOŃCZENIE}

Zastosowanie metody scenariuszy stanów otoczenia do analizy rynku książki miało na celu lepszą identyfikację tych składników makrootoczenia, które mogą mieć decydujący wpływ na funkcjonowanie rynku książki. Ponadto zastosowanie scenariuszy miało na celu wyznaczenie różnych możliwych ścieżek rozwoju tego rynku z punktu widzenia otoczenia zewnętrznego. Jego uwarunkowania winny być jednak poddane dalszej pogłębionej analizie, także w skali np. krajowej. Dodać należy, że omawiając otoczenie rynku książki starano się uwzględnić takie czynniki (procesy), które rzeczywiście mają wpływ na jego funkcjonowanie, a jednocześnie mają charakter uniwersalny i mogą mieć zastosowanie przy analizie rynku książki w różnych układach przestrzennych.

Na podstawie otrzymanych wyników wydaje się, że najprawdopodobniej nastąpi dalszy wzrost dostępu do tekstu książki, w oparciu o nowoczesne technologie tak z pozycji czytającego, jak i potencjalnego autora. Ale to technologiczne ułatwienie może być okupione - świadomą lub nie - inwigilacją, a nawet manipulacją, która może wymuszać określone zachowania popytowe, a w konsekwencji zakupowe.

Jeżeli uznamy, że przeprowadzona diagnoza przynajmniej w części jest trafna, to na jej podstawie można przygotować strategię reagowania na zewnętrzne szanse i zagrożenia. Kluczowe wydaje się pytanie o odpowiedzialność instytucjonalną za takie działania na poziomie operacyjnym i strategicznym. Zachodzące procesy świadczą raczej o nieuchronności zmian, a odpowiedź na istotne w tym kontekście pytanie o to, czy jesteśmy na nie przygotowani mentalnie, organizacyjnie, prawnie i ekonomicznie, nie napawa optymizmem.

Książka, mimo wielu głosów sprzeciwu, jest towarem, a ten podlega prawom rynku. Stąd tak duża rola sfery ekonomicznej w otoczeniu rynku książki. Cena jako główna przewaga konkurencyjna może okazać się krótkowzroczna, a nadpodaż elementem nie do udźwignięcia przez wielu graczy rynkowych. Dlatego kluczowe w tym kontekście wydaje się pytanie o to, jaką funkcję na rynku będzie pełniła książka w przyszłości.

Kluczowym czynnikiem decydującym o dalszym rozwoju wszystkich ogniw rynku książki będzie jednak czynnik społeczno-kulturowy, który związany jest z przejściem w kierunku społeczeństwa informacyjnego (hipertekstowego), w którym istotna jest sama informacja (jej szybkość, elastyczność, selektywność) oraz wygodny nośnik jej przekazu. Książka, będąc wytworem świata analogowego, traci więc nie tylko jako źródło często obszernej, kontekstowej informacji, ale również jako mało elastyczny jej nośnik.

\section{Literatura \\ References}

Augustyn., K. (2017). Od produktu do usługi. Przemiany na rynku książki w epoce nowych mediów. Folia Bibliologica, LIX, 71-95.

Dobrowolski, Z. (2001). Nowe formy książki. Możliwości i zagrożenia. Przegląd Biblioteczny, 3, 199-207.

Drapińska, A., Liberadzka, B. (2017). Trendy na rynku książki w Polsce - wybrane aspekty. Handel Wewnętrzny, 5(370), 111-120.

Gierszewska, G., Romanowska, M. (2002). Analiza strategiczna przedsiębiorstwa. Warszawa: Polskie Wydawnictwo Ekonomiczne.

Gołębiewski, Ł. (2010). Rynek książki w Polsce 2010. Warszawa: Biblioteka Analiz. 
Koryś, I., Michalak, D., Zasacka, Z., Chymkowski, R. (2018). Stan czytelnictwa w Polsce w 2017 roku. Warszawa: Biblioteka Narodowa.

Kozioł, K. (2010). Analiza strategiczna przedsiębiorstwa na poziomie makrootoczenia. Studia i Prace Wydziału Nauk Ekonomicznych i Zarzq̨dzania Uniwersytetu Szczecińskiego, 17, 77-88.

Kwiecińska, M. (2016). Wybrane metody analizy strategicznej otoczenia w planowaniu operacji reagowania kryzysowego - ujęcie teoretyczne. Obronność, 2(18), 108-128.

McLuhan, M. (1962). The Gutenberg Galaxy: the making of typographic man. Toronto: University of Toronto.

Osiewała, R. (2013). Czy biblioteki i książki przetrwaja próbę czasu: od książki drukowanej do e-książki, od biblioteki tradycyjnej do wirtualnej. Łódź: Wydawnictwo Uniwersytetu Łódzkiego.

Penc-Pietrzak, I. (2010). Planowanie strategiczne w nowoczesnej firmie. Warszawa: Wolters Kluwer Polska.

Rychlewski, M. (2013). Książka jako towar - książka jako znak. Gdańsk: Katedra - Wydawnictwo Naukowe.

Turrin, E. (2017). The book sector in Europe: facts and figures. Federation of European Publishers. Zygierewicz, A. (2015). Rynek ksiq̨żki w wybranych państwach. Warszawa: Biuro Analiz Sejmowych.

Anna Czaplińska, dr, adiunkt, Katedra Geografii Społeczno-Ekonomicznej, Instytut Gospodarki Przestrzennej i Geografii Społeczno-Ekonomicznej, Wydział Ekonomii, Finansów i Zarządzania, Uniwersytet Szczeciński. Zainteresowania badawcze są związane z problematyką geografii społecznej i kulturowej, w tym z krajobrazem kulturowym, procesami akulturacji oraz kulturowymi uwarunkowaniami kreowania marketingu terytorialnego.

Anna Czaplińska, PhD, assistant professor, Department of Socio-Economic Geography, Institute of Spatial Management and Socio-Economic Geography, Faculty of Economics, Finance and Management, University of Szczecin. Her research interests are related to the issues of social and cultural geography, including the cultural landscape, the processes of acculturation and the cultural determinants of creating territorial marketing.

ORCID: https://orcid.org/0000-0002-6294-5101

\section{Adres/address:}

Uniwersytet Szczeciński

Wydział Ekonomii, Finansów i Zarządzania

Instytut Gospodarki Przestrzennej i Geografii Społeczno-Ekonomicznej

Katedra Geografii Społeczno-Ekonomicznej

ul. Mickiewicza 18, 70-383 Szczecin, Polska

e-mail: anna.czaplinska@usz.edu.pl 